\title{
Pesan Dakwah dalam Produk Anak Muslim Afrakids
}

\author{
Septi Nurjamilatunnisa ${ }^{1}$, Ahmad Sarbini $^{2}$, \& Moch. Fakhruroji ${ }^{3}$ \\ ${ }^{1} J u r u s a n$ Komunikasi dan Penyiaran Islam, Fakultas Dakwah dan Komunikasi, \\ UIN Sunan Gunung Djati, Bandung \\ 2Jurusan Managemen Dakwah, Fakultas Dakwah dan Komunikasi, \\ UIN Sunan Gunung Djati, Bandung \\ ${ }_{3}^{3} J u r u s a n$ Ilmu Komunikasi, Fakultas Dakwah dan Komunikasi, \\ UIN Sunan Gunung Djati, Bandung
}

\begin{abstract}
This study aims to determine the categorization of da'wah messages including the message of faith, moral messages and sharia messages contained in the catalog of shirts. The method used in this study is to use analytical methods using symbol coding, reporting and interpretation techniques. Using data reporting techniques, literature study and categorization. In this study it can be concluded that Afrakids Muslim children's products have a message category with a total of 2 messages or a percentage of $7.7 \%$, has a message categorization with a total of 18 messages or a percentage of $69.2 \%$, and has a sharia message categorization with a total of 6 messages or percentage of $23.1 \%$. Of the three categorization messages of da'wah, do more using messages for children in instilling the values of Islamic teachings in daily life. Followed by the Sharia message and the least message of faith.
\end{abstract}

Keywords: message da'wah; muslim children's products; popular culture

\begin{abstract}
ABSTRAK
Penelitian ini bertujuan untuk mengetahui kategorisasi pesan dakwah meliputi pesan akidah, pesan akhlak serta pesan syariah yang ada pada katalog kaos tersebut. Adapun metode yang dilakukan dalam penelitian ini adalah menggunakan metode analisis isi dengan menggunakan teknik symbol coding, mencatat lambang atau pesan secara sistematis kemudian diberi interpretasi. Adapun teknik pengumpulan datanya melalui dokumentasi, studi pustaka dan kategorisasi. Dalam penelitian ini dapat disimpulkan bahwa produk anak muslim Afrakids memiliki kategori pesan akidah dengan jumlah 2 pesan atau persentase sebanyak 7,7\%, memiliki kategorisasi pesan akhlak dengan jumlah 18 pesan atau persentase sebanyak $69,2 \%$, dan memiliki kategorisasi pesan syariah dengan jumlah 6 pesan atau persentase sebanyak 23,1\%. Dari ketiga kategorisasi pesan dakwah tersebut, cenderung lebih banyak menggunakan pesan akhlak untuk anak dalam menanamkan nilai-nilai ajaran Islam dalam kehidupan sehari-hari. Disusul dengan pesan syariah dan pesan akidah yang paling sedikit.
\end{abstract}

Kata Kunci : pesan dakwah; produk anak muslim; budaya populer 


\section{PENDAHULUAN}

Peranan umat muslim untuk berdakwah dalam kehidupan manusia semakin besar maknanya. Hal ini terlihat dari kemajuan arus globalisasi yang menjadi ancaman besar terkikisnya identitas dan integritas moral masyarakat. Arus globalisasi mampu membuat kemajuan di bidang teknologi informasi dengan dampak baik ataupun buruk, namun dengan adanya kemajuan dalam bidang teknologi informasi pun mampu mempermudah tugas umat muslim sebagai khalifah di muka bumi untuk menjalankan perintah serta menyampaikan anjuran Islam dalam menjalankan konsep amar ma'ruf nahi munkar, yaitu dengan mengajak serta menganjurkan hal-hal yang baik dan mencegah hal-hal yang buruk.

Dampak buruk dari perkembangan teknologi informasi salah satunya adalah masyarakat yang relatif mudah menerima budaya barat. Hal ini dikarenakan filter dari masing-masing individu masyarakat yang kurang dipergunakan dengan maksimal, sehingga mereka dengan mudah menerima budaya-budaya barat tersebut secara mentah. Padahal, belum tentu budaya barat yang dianggap modern itu sesuai dengan etika maupun norma yang berlaku di tengah masyarakat.

Budaya merupakan suatu cara hidup yang diwariskan dari generasi ke generasi. Unsur yang terbentuk di dalam budaya bisa dikatakan sangat rumit karena terbentuk dalam system agama dan politik, adat istiadat, pakaian, bahasa, bangunan, karya seni sampai dengan makanan (Wikipedia, 2017). Komunikasi mampu menjadi peranan yang penting dalam pemahaman terhadap budaya dan pengaruh budaya dalam perilaku sehari-hari. Seiring perkembangan zaman, istilah budaya populer atau budaya pop pun lahir dalam pengaktualisasiannya mendapat dukungan dari penggunaan perangkat teknologi tinggi sehingga masyarakat dengan mudah menerapkannya dalam kehidupan sehari-hari (Imanto, 2012: 1).

Budaya populer merupakan dialektika antara homogenisasi yaitu penyeragaman dan heterogenisasi yaitu keragaman (Simatupang, 2006: 16). Budaya populer tersebut merupakan sebuah budaya ataupun produk budaya yang disukai dan disenangi oleh masyarakat yang sering dianggap sebagai salah satu kebudayaan instan yang cenderung melawan suatu proses sehingga golongan masyarakat yang bersebrangan menganggap sebagai budaya dengan peradaban dangkal pemikiran, tanpa nilai, kabur, cari sensasi, berprilaku rusak dan masyarakat berjiwa konsumtif dan hedonis (Imanto, 2012: 2).

Menanggapi permasalahan tersebut, sudah menjadi kewajiban umat muslim berkontribusi dalam perubahan sosial masyarakat. Dakwah merupakan ajakan atau seruan untuk mengajak kepada seseorang atau sekelompok orang untuk mengikuti dan mengamalkan ajaran dan nilai-nilai Islam. Bagi yang belum Islam diajak menjadi muslim dan bagi yang sudah Islam diajak menyempurnakan keislamannya dan bagi yang sudah mendalam di dorong untuk mengamalkan dan menyebarkannya (Darmawan, 2004: 24).

Hanya saja semua itu tidak terikat kepada siapa yang harus menyebarkan serta mengajak manusia ke dalam ajaran dan nilai-nilai Islam. Karena sejatinya 
semua manusia di muka bumi ini adalah khalifah yang berkewajiban untuk mengemban tugas dakwah. Selama ini tujuan dakwah hanya ditekankan terhadap cara penyampaian informasi atau pesan-pesan keagamaan terhadap masyarakat, bukan terhadap bagaimana pesan tersebut dapat diterima serta dilaksanakan secara sadar oleh masyarakat untuk hidup yang lebih baik.

Peran dakwah disini haruslah dikemas dengan cara dan media yang tepat. Dakwah harus tampil secara aktual, faktual dan kontekstual. Aktual dalam arti memecahkan masalah yang kekinian dan hangat di tengah masyarakat. Faktual dalam arti konkret dan nyata, serta kontekstual dalam arti relevan dan menyangkut problema yang sedang dihadapi masyarakat (M. Munir, 2003: ix). Oleh karena itu pemilihan bentuk dakwah yang tepat, aktual faktual dan kontekstual menjadi bagian strategis dari kegiatan dakwah itu sendiri.

Dalam hal tersebut, proses komunikasi dakwah merupakan kegiatan mengubah sikap, sifat, pendapat, dan tingkah laku orang lain sesuai dengan keinginan komunikator (da'i). Sedangkan untuk mencapai tujuan tersebut, diperlukan strategi maupun teknik operasional komunikasi yang harus dilakukan da'i, selain peta jalan yang menunjukkan arah yang harus ditempuhnya. (Mubasyaroh, 2017: 312)

Tabligh merupakan salah satu dimensi kerisalahan dakwah dalam menyampaikan pesan kebenaran. Dalam dimensi kerisalahan dakwah, mencoba menumbuhkan kesadaran diri tentang kebenaran nilai dan pandangan hidup secara Islam, sehingga terjadi proses internalisasi nilai Islam sebagai nilai hidupnya. Dengan kata lain, dakwah kerisalahan dalam praktiknya merupakan proses mengkomunikasikan dan menginternalisasikan nilai-nilai Islam (Sumijati, 2004: viii). Salah satu bentuk tabligh yang berkembang adalah tabligh melalui tulisan atau kitabah. Termasuk didalamnya seperti risalah, majalah, artikel, cerpen, sajak, poster, internet, lukisan, kaligrafi ataupun foto yang mengandung pesanpesan keIslaman.

Dewasa kini pemanfaatan media produk anak muslim dianggap lebih efektif dalam penyampaian pesan dakwah. Hal itupun dilakukan oleh salah satu brand kaos muslim anak Afrakids yang berada di Jalan Raya Pasir Putih Sawangan Depok, dalam pemanfaatan hasil produk budaya populer dalam mempromosikan produk yang dikhususkan untuk kebutuhan anak muslim.

Objek penelitian yang dilakukan terhadap produk anak muslim afrakids dengan menggunakan media internet dalam website www.Afrakids.com sebagai wadah dalam mengidentifikasi semua produk tersebut. Pemilihan produk anak muslim afrakids sebagai objek penelitian karena didalamnya terdapat pesan dakwah yang dikemas secara menarik dengan memadukan antara budaya populer dengan penggunaan metode kitabah atau dakwah melalui tulisan. Selanjutnya akan dikaji lebih dalam bagaimana pesan dakwah menggunakan kategorisasi konten pesan sesuai materi ajaran Islam secara umum.

Pemilihan konten dakwah tentang tema keseharian seperti all about shalat, rabb's creation, how to eat, enthusiastic learner, muslim attitude, happy daughter, follow rasulullah yang ditujukan untuk anak muslim, diharapkan produk tersebut mampu 
menjadi salah satu alternatif dalam menanamkan nilai-nilai agama dalam pengaruh budaya populer tersebut.

Teori yang dijadikan landasan dalam penelitian ini adalah teori dakwah dan tabligh, pesan dakwah dan budaya populer. Dakwah menurut Bahasa merupakan mengajak, menyeru, mengundang dan memanggil. Adapun dakwah dalam penelitian ini adalah dengan menggunakan pengertian dakwah khusus yaitu dakwah Islam yang berarti upaya merubah situasi, mendorong, menyeru dan menghimpun manusia kepada ajaran Islam. Upaya tersebut dilakukan dengan bentuk amar ma'ruf nahi munkar, serta upaya itu dimaksudkan agar manusia berbahagia di dunia dan akhirat kelak (Ardi, 2013: 4).

Dalam prosesnya dakwah bukan hanya merupakan fenomena keagamaan saja, namun juga fenomena sosial berlangsung dalam proses sosial memiliki implikasi sosial. Itu artinya selain seorang da'i mengajak dalam praktik keagamaan seperti penerapan ajaran akidah dan syariah namun juga menerapkan ajaran akhlak dalam melakukan kebajikan dan mencegah kemunkaran. Selain dari usaha dalam penyebaran dan pemerataan ajaran agama Islam, dakwah juga merupakan suatu kegiatan dalam proses mengkomunikasikan ajaran agama Allah SWT yang sesuai dalam al-Qur'an dan as-Sunah.

Tabligh menurut kamus besar Arab-Indonesia merupakan Bahasa arab yang berasal dari akar kata ballagha, yuballighu, tablighan yang berarti menyampaikan. Sedangkan dalam konteks ajaran Islam, tabligh adalah penyampaian dan pemberitaan tentang ajaran-ajaran Islam kepada umat manusia, yang dengan penyampaian dan pemberitaan tersebut, pemberita terlepas dari kewajiban memberitakan dan pihak penerima berita menjadi terikat dengannya (Sukayat, 2009: 88).

Lebih spesifik dan identik, tabligh meliputi (1) khitabah dan (2) kitabah. Kitabah merupakn tabligh yang dilakukan memlalui media cetak seperti risalah, majalah, artikel, cerpen, sajak, poster, buku, internet, koran dan tulisan-tulisan yang mengandung pesan dakwah merupakan proses penyampaian ajaran Islam. Termasuk juga didalamnya berupa lukisan, kaligrafi, foto yang mengandung pesan-pesan keislaman.

Pesan merupakan apa yang dikomunikasikan oleh sumber kepada penerima. Selain pesan merupakan seperangkat symbol verbal dan non verbal yang mewakili perasaan, nilai, gagasan, maksud sumber tadi, pesan itu sendiri memiliki tiga komponen yaitu symbol yang digunakan untuk menyampaiakn makna dan bentuk atau organisasi pesan (ilaihi, 2013: 97).

Pesan verbal atau pesan linguistik adalah pesan yang digunakan dalam komunikasi dengan menggunakan bahasa sebagai media. Bahasa verbal ditransmisikan dengan kombinasi bunyi Bahasa serta digunakan untuk menyatakan pikiran, perasaan dan maksud. Sehingga verbal dapat dipahami sebagai pesan yang diungkapkan dengan Bahasa dengan menggunakan kata-kata sebagai representasi realitas atau maknannya (Laksana, 2015: 153).

Sedangkan pesan nonverbal merupakan semua tanda atau isyarat yang tidak 
berbentuk kata-kata. Dalam pesan nonverbal memiliki symbol symbol sebagai "tanda pengingat" dalam human memory-nya, sehingga dapat menciptakan dan menemukan ide-ide baru yang lebih mudah disebarluaskan, bahkan merangsang timbulnya gagasan-gagasan baru yang lebih baik (Liliweri, 2011: 3).

Dengan demikian, pesan nonverbal mencakup seluruh perilaku yang tidak berbentuk verbal yang disengaja atau tidak disengaja sebagai bagian dari peristiwa komunikasi secara keseluruhan, serta dengan adanya pesan nonverbal mampu merangsang timbulnya gagasan.

Kategorisasi pesan dakwah dapat diambil sesuai dengan ajaran agama Islam yang terdapat dalam al-Qur'an sebagai pedoman hidup manusia, as-Sunah Rasulullah SAW, hasil ijtihad para ulama dan sejarah peradaban Islam. Dalam buku Ilmu Dakwah secara umum materi pesan dakwah diklasifikasikan menjadi tiga masalah pokok, yaitu pesan akidah, pesan syariah dan akhlak (ilaihi, 2013: 20)

Pertama, pesan akidah. Akidah menurut Bahasa merupakan menghubungkan dua sudut sehingga bertemu dan bersambung secara kokoh. Dalam perundang-undangan akidah merupakan menyepakati antara dua perkara atau lebih yang harus di patuhi bersama (Nata, 2009: 84). Karakteristik Islam yang dapat diketahui melalui bidang akidah ini adalah bahwa akidah Islam bersifat murni baik dalam isinya maupun prosesnya. Akidah dalam Islam meliputi keyakinan dalam hati bahwa hanya Allah SWT Tuhan yang wajib disembah; ucapan dengan lisan dalam bentuk dua kalimat syahadat. Namun bukan berarti hanya dalam ucapan saja, melainkan secara keseluruhan menggambarkan Iman kepada Allah SWT, yakni tidak ada niat, ucapan ataupu perbuatan yang dikemukakan oleh orang yang beriman itu kecuali yang sejalan dengan kehendak Allah SW'T.

Kedua, pesan syariah. Materi dakwah dalam pesan syariah harus menggambarkan atau memberikan informasi yang jelas di bidang hokum dalam status hokum yang bersifat wajib, mubah (dibolehkan) dan haram (dilarang) (Munir, 2009: 27). Dalam pesan syariah terbagi kedalam dua bagian, yaitu ibadah dan muamalah. Ibadah merupakan tata cara menyembah Allah SW'T dengan tidak mempersekutukannya. Sedangkan muamalah merupakan interaksi dan komunikasi antar sesama manusia dengan manusia lain sebagai makhluk sosial dalam rangka hablu man al-nas (Sukayat, 2009: 33).

Ketiga, pesan akhlak. Akhlak merupakan budi pekerti, adat kebiasaan, perangkai, muruah atau sesuatu yang telah menjadi tabiat. Akhlak pun merupakan sifat yang tertanam dalam jiwa seseorang yang berakibat timbulnya berbagai perbuatan secara spontan tanpa disertai pertimbangan (Wahyudi, 2017: 2). Adapun pembagian akhlak berdasarkan sifatnya ada dua, (1) akhlak mahmudah (akhlak terpuji) serta yang kedua akhlak mazhmumah (akhlak tercela).

Budaya populer bagi para kritikus budaya massa dapat didefinisikan sebagai budaya rakyat di dalam masyarakat pra-industri, atau budaya massa dalam masyarakat industry (Strinati, 2007: xxx). Pada dasarnya budaya populer dibuat oleh masyarakat, tidak dihasilkan oleh industry budaya. Karena yang dapat dilakukan oleh industri-industri budaya hanyalah menghasilkan repertoar teks atau 
sumber daya budaya bagi pelbagai formasi masyarakat untuk digunakan atau di tolak dalam proses yang sedang berlanjut dalam menghasilkan budaya populer mereka (Fiske, 2011: 26).

Oleh karenannya budaya populer dibuat oleh orang-orang bukan diterapkan kepada mereka. Hal tersebut datang dari dalam dan bawah, bukan dari atas. Menurut deCertau (1984) budaya populer adalah seni mengolah apa yang dihasilkan oleh system. Kita hidup di dalam masyarakat industri, sehingga budaya populer merupakan budaya yang terindustrialisasi serta merupakan sumber daya.

Adapun karakteristik budaya populer menurut (Rahman, 2009: 5) adalah tren, keseragaman bentuk, adaptabilitas, durabilitas dan profitabilitas. Tren merupakan sebuah budaya yang diikuti atau disukai banyak orang. Keseragaman bentuk merupakan sebuah ciptaan manusia yang menjadi tren akhirnya diikuti oleh banyak copycat-penjiplak. Adaptabilitas merupakan sebuah budaya populer yang mudah dinikmati dan diadopsi oleh khalayak. Durabilitas merupakan budaya populer akan dilihat berdasarkan durabilitas menghadapi waktu, pionir budaya populer yang dapat mempertahankan dirinya bila pesaing yang kemudian muncul tidak dapat menyaingi keunikan dirinya, akan bertahan. Sedangkan profitabilitas dilihat dari sisi ekonomi, budaya populer berpotensi menghasilakn keuntungan yang besar bagi industry yang mendukungnya.

Ada beberapa tren saluran budaya populer yang digandrungi saat ini dan menjungjung tinggi perubahan yaitu, televise, fiksi, film, surat kabar dan majalah, music pop dan konsumsi dalam kehidupan sehari-hari. Salah satu tren saluran budaya populer adalah majalah. Majalah memiliki peran dalam menyampaikan pesan dengan memadukan antara tulisan dan verbal. Majalah biasanya terdapat katalog yang berisi daftar barang atau produk yang disertai gambar.

Budaya populer memiliki cakupan dalam gaya berpakaian atau fashion. Dengan demikian tidak sedikit gaya berpakaian yang berusaha mengeksploitasinya bagi kepentingan bisnis. Dalam strategi pemasaran dan periklanannya, mereka berusaha menargetkan kelompok-kelompok sosial spesifik sehingga mampu memberikan produk yang menjadi cerminan yang lebih spesifik.

Dari latar belakang masalah tersebut dapat dirumuskan beberapa masalah dengan rumusan bagaimana kategorisasi pesan akidah, pean akhlak dan pesan syariah dalam produk anak muslim afrakids.

Metode yang digunakan dalam penelitian ini adalah metode analisis isi atau content analysis. Penelitian ini bersifat pembahasan yang mendalam terhadap isi suatu informasi tertulis atau tercetak dengan menggunakan teknik symbol coding, yaitu mencatat lambang atau pesan secara sistematis, kemudian diberi interpretasi. Dimana metode ini menekankan pada pembuatan inferensi atau simpulan secara kontekstual, sehingga pesan-pesan komunikasi didalam sebuah teks dapat dipahami secara utuh. Dalam kaitannya dengan penelitian ini, metode analisis isi dapat bertujuan untuk mengungkap apa dan bagaimana pesan dakwah dalam produk anak muslim afrakids dalam mengidentifikasi serta menganalisis kedalam bentuk kategori-kategori pesan. 


\section{HASIL DAN PEMBAHASAN}

Penelitian ini dilakukan dalam website resmi Afrakids, sebuah brand kaos anak muslim di Sawangan Depok. Afrakids hadir karena kondisi umat saat ini yang tidak sehat, terlampau banyak peristiwa terjadi yang mampu menggambarkan betapa umat telah banyak meninggalkan nilai-nilai ajaran Islam. Afrakids yang hadir atas keresahan terhadap kondisi umat, ingin mendorong perubahan besar. Perubahan memang tidak akan terjadi jika hanya Afrakids saja yang memulai. Oleh sebab itu, Afrakids memilih untuk menjadi agen perubahan yang melahirkan orang-orang yang mampu menciptakan perubahan. Semua perubahan itu Afrakids mulai dari unit-unit terkecil masyarakat, yaitu keluarga.

Afrakids yang hadir dengan mendorong perubahan dibentuk oleh Hisyam dan Maula yang dipertemukan di sebuah pelatihan internet marketing atau National Bootcamp (NBC) di daerah Solo. Dengan tiga kekuatan yang dimiliki Afrakids, yaitu (1) desain, (2) konten (3) digital. Dari ketiga kekuatan tersebut, Afrakids hadir menciptakan produk anak muslim yang bertujuan agar anak-anak dapat lebih mudah dalam mengenal nilai-nilai Islam. Serta orangtua semakin memiliki kesadaran yang tinggi dalam mengajarkan nilai-nilai Islam kepada anaknya. Dengan mengusung kekuatan demi tujuan dalam emndorong perubahan, Afrakids pun memiliki cita-cita untuk terus bergerak dan mengajak semua umat untuk menyelesaikan segala permasalahan di masyarakat dari mulai keluarga melalui penanaman nilai-nilai Islam. Sebab Afrakids percaya bahwa itu adalah cara yang paling efektif dalam melahirkan perubahan yang berarti.

Hasil penelitian ini menemukan pesan dakwah yang terkandung dalam kaos anak muslim Afrakids. Konten atau tema kaos tersebut yaitu all about shalat, enthusiast learner, follow rasulullah $S A W$, happy daughter, how to eat, muslim attitude dan rabb creation. Dari ketujuh tema tersebut, terdapat 34 judul kaos. Namun yang diteliti hanya 26 judul kaos berdasarkan hasil coding. Sesuai dengan lembar coding, dapat disimpulkan bahwa jumlah kategorisasi pesan akhlak terdapat 18 pesan, kategorisasi pesan akidah terdapat 2 pesan sedangkan kategorisasi pesan syariah terdapat 6 pesan. Dengan indeks reliabilitas, kesepakatan antar pelaku coding mengenai kategori produk anak muslim Afrakids adalah tinggi. Karena menghasilkan jumlah yang jika dipersentasikan menghasilkan $76 \%$, perhitungan tersebut sesuai dengan pengukuran indeks Guilford yakni 70-90\% korelasi yang tinggi atau kuat (Hidayat, 2012).

\section{Kategorisasi Pesan Akidah}

Berdasarkan hasil coding, kategorisasi pesan akidah atau pesan yang berkaitan dengan masalah keimanan pada pesan dakwah yang terdapat dalam produk anak muslim Afrakids sebanyak 3 pesan, yaitu: 
Tabel 1 Pesan Dakwah Kategori Akidah

\begin{tabular}{ll}
\hline Judul Pesan & Kategorisasi Pesan Akidah \\
\hline Under The Sea it's My Rabb's Creation & Iman Kepada Allah SWT \\
Earth \& Sky Are My Rabb Creation & Iman Kepada Allah SWT \\
\hline
\end{tabular}

Sumber: Hasil Penelitian

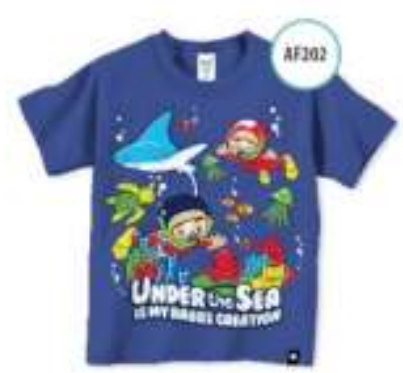

Sumber: Katalog Afrakids

Gambar 1. Salah satu contoh kategorisasi pesan akidah

Kategorisasi pesan dakwah yang mengacu pada pesan akidah dalam tabel 1 memiliki 3 judul dalam produk anak muslim Afrakids. Akidah merupakan keyakinan dalam hati bahwa hanya Allah SWT Tuhan yang wajib disembah, ucapan dengan lisan dalam bentuk dua kalimat syahadat yaitu menyatakan tidak ada Tuhan selain Allah SWT dan Nabi Muhammad sebagai utusan-Nya. Selain itu harus meyakini bahwa keimanannya terhadap malaikat-Nya, kitab-kitab-Nya, rasul-rasul-Nya, hari akhir maupun qadha dan qadhar. Namun bukan berarti hanya ucapan dimulut saja, melainkan secara keseluruhan menggambarkan Iman kepada Allah SWT, yakni tidak ada niat, ucapan ataupun perbuatan yang dikemukakan oleh orang yang beriman itu kecuali yang sejalan dengan kehendak Allah SW'T.

Iman kepada Allah SWT merupakan bentuk keyakinan dan kepercayaan seorang hamba kepada Allah SW'T bahwa hanya Allah SWT lah yang patut disembah. Membenarkan dengan hati bahwa Allah SWT benar-benarada dengan segala sifat kesempurnaan-Nya serta mengamalkan segala perintah dan laranganNya. Berdasarkan pengertian tersebut, iman kepada Allah SWT merupakan suatu kepercayaan yang harus diyakini bahwa Allah SWT adalah pencipta seluruh alam semesta. Adapun pesan dakwah yang terdapat dalam kaos Afrakids menjelaskan tentang salah satu bentuk keyakinan terhadap Allah SWT, yaitu:

Under the sea it's my Rabb creation yang berarti bawah laut adalah ciptaan Rabb saya merupakan salah satu kategori pesan akidah dalam beriman kepada Allah SWT. Kaos tersebut mengajarkan anak-anak untuk melihat kebesaran yang dimiliki Allah SWT. Allah itu Rabbul alamiin yang artinya pencipta dan pemelihara 
alam semesta. Oleh karena itu Allah SWT pun disebut juga Khaliq yang artinya pencipta. Sedangkan alam dan seisinya disebut makhluk yang artinya diciptakan. Dalam al-Qur'an surat al-Baqarah ayat 136:

"Katakanlah (hai orang-orang mukmin): "kami beriman kepada Allah SWT dana pa yang diturunkan kepada kami, dana pa yang diturunkan kepada Ibrahim, Ismail, Ishaq, Yaqub dan anak cucunya, dana pa yang diberikan kepada Musa dan Isa serta apa yang diberikan kepada nabi-nabi dari Tuhannya. Kami tidak membeda-bedakan seorangpun diantara mereka dan kami hanya tunduk dan patuh kepada-Nya." (Depag RI, 2009:21).

Beriman kepada Allah SWT adalah membenarkan dengan hati bahwa Allah SWT ada dengan sifat keagungan serta kesempurnaannya, selanjutnya diakui dengan lisan dan dibuktikan dengan amal perbuatan yang nyata. Bumi, langit dan lautan merupakan bukti keesaan serta kebesaran Allah SWT. Keindahan serta kehebatan yang Allah SW'T ciptakan menunjukan bahwa betapa agung-Nya Allah SWT yang telah menciptakan. Allah SWT menciptakan bumi dan seisinya tiada lain hanya untuk kepentingan hidup manusia, karena manusia yang Allah SWT jadikan sebagai khalifah di muka bumi.

Allah SWT menciptakan manusia sebagai makhluk yang paling mulia, sedangkan bumi, langit laut dan segalanya diciptakan untuk kebutuhan hidup manusia untuk diolah, diatur serta dipelihara sebaik-baiknya agar mendapatkan kesejahteraan dalam hidup manusia. Adapun fungsi dari beriman kepada Allah SW'T yaitu mampu menambah keyakinan bahwa Allah SWT lah yang telah menciptakan segala sesuatu dengan kehendaknya. Serta mampu menambah ketaatan bahwa dengan beriman kepada Allah SWT serta menjauhi larangan-Nya, sehingga hati kita akan selalu ingat kepada Allah SWT.

Sebagai manusia yang menjadi khalifah di muka bumi hendaklah semua itu digunakan sebagai bekal untuk mengabdi dan berbakti kepada Allah SWT sebagai tanda syukur kepada-Nya. Dengan cara itulah merupakan salah satu contoh perilaku beriman kepada Allah SWT.

Earth and sky are my Rabb creation yang berarti bumi dan langit adalah ciptaan Rabb saya merupakan salah satu kategori pesan akidah dalam beriman kepada Allah SWT. Dalam penjelasan katalognya, Afrakids mengatakan bahwa Anakanak ayah dan bunda harus diberitahu tentang kebesaran Allah SWT, salah satunya tentang bumi dan langit yang telah Allah SWT ciptakan. Melalui kaos ini anak-anak dapat dikenalkan tentang kebesaran Allah SWT sebagai Sang Pencipta alam semestra.

Sama halnya dengan under the sea it's my rabb's creation, earth and sky are my Rabb creation yang berarti bumi dan langit adalah ciptaan Rabb saya merupakan kategorisasi pesan akidah kedua dalam beriman kepada Allah SWT. Under the sea it's my Rabb, menunjukan bahwa salah satu sifat wajib bagi Allah SWT yang patut di yakini adalah Qudrat dan Iradat. Allah SWT itu Qudrat yang artinya kuasa serta Iradat yang artinya berkehendak. Jika Allah SWT telah berkuasa dalam berkehendak dalam menciptakan sesuatu, maka jadilah semua itu. 
Allah SWT bersifat Qudrat yang berarti Allah SWT Mahakuasa, atau memiliki kekuasaan. Allah SWT berkuasa menciptakan alam semesta serta mampu memelihara dan sanggup menghancurkannya tanpa bantuan dan pertolongan siapapun. Kekuasaan Allah SWT tidak terbatas. Bila Allah SWT memiliki sifat wajib Qudrat atau kuasa mustahil bagi-Nya memiliki kelemahan.

Selanjutnya salah satu sifat wajib bagi Allah SWT bersifat Iradat yang artinya berkehendak ataupun berkemauan. Allah SWT memiliki kehendak dan dapat melakukan apa saja yang dikehendaki-Nya, seperti menciptakan alam semesta dan seluruh isinya. Allah SWT melakukan sesuatu sesuai kehendaknya dan mustahil Allah SWT itu memiliki sifat Karoohah atau melakukan sesuatu dengan terpaksa. Sejatinya kehendak Allah SWT itu dilakukan dengan kemauan-Nya bukan karena dipaksa oleh siapapun. Berbeda dengan manusia, meski manusia memiliki kehendak namun kehendak dan keinginan manusia berada di bawah kendali kehendak Allah SWT. Allah SW'T lah yang menentukan apa yang akan terjadi pada manusia. Jika Allah SWT telah berkehendak segala sesuatu akan terjadi.

Berdasarkan pengertian akidah menurut (Ritonga, 2002: 4) meliputi enam perkara, yaitu (1) ma'rifat kepada Allah SWT. (2) ma'rifat kepada alam ghaib. (3) ma'rifat kepada kitab-kitab Allah. (4) ma'rifat kepada para nabi dan rasul Allah. (5) ma'rifat kepada hari akhir. (6) ma'rifat kepada qadar (takdir) baik dalam penciptaan maupun pengaturannya. Dari kedua judul kaos tersebut memiliki pesan akidah dalam beriman kepada Allah SW'T atau ma'rifat kepada sifat-Nya yang tinggi serta ma'rifat terhadap dalil wujud-Nya dan fenomena-fenomena keagungan-Nya di alam semesta ini.

\section{Kategorisasi Pesan Akhlak}

Berdasarkan hasil coding, kategorisasi pesan akhlak atau pesan yang berkaitan dengan masalah budi pekerti pada pesan dakwah yang terdapat dalam produk anak muslim Afrakids sebanyak 18 pesan, yaitu:

Kategorisasi pesan dakwah yang mengacu pada pesan akhlak dalam tabel 2 memiliki 18 judul dalam produk anak muslim Afrakids. Akhlak merupakan sifat yang tertanam dalam jiwa sehingga seseorang dapat menilai perbuatan baik atau buruk yang kemudian memilih untuk melakukan atau meninggalkannya. Akhlak tidak hanya sebagai media yang mencakup hubungan manusia dengan Allah SWT tetapi juga mencakup hubungan manusia dengan sesamanya ataupun dengan alam sekitarnya karena sejatinya Islam adalah Rahmatan lil 'aalamiin.

Akhlak bersumber dari apa yang menjadi ukuran baik dan buruk atau mulia dan tercela. Sebagaimana keseluruhan ajaran Islam, sumber akhlak adalah alQur'an dan as-Sunnah, bukan akal pikiran atau pandangan masyarakat sebagaimana pada konsep etika dan moral. Akhlak yang baik dan mulia merupakan sifat Rasulullah SAW dan yang paling utama diantara segala amalan para shaddiqin. Akhlak dalam Islam bukanlah norma ideal yang tidak dapat diimplementasikan dan bukan pula sekumpulan etika yang terlepas dari kebaikan norma sejati. Namun materi akhlak dalam Islam mengenai sifat dan kriteria 
perbuatan manusia serta berbagai kewajiban yang harus dipenuhinya.

Tabel 2 Pesan Dakwah Kategori Akidah

\begin{tabular}{ll}
\hline Judul Pesan & Kategorisasi Pesan Akhlak \\
\hline Salam is Spreading Peace & Akhlak Terhadap Sesama Manusia \\
Alhamdulillab I Finished my meat & Akhlak Terhadap Allah SWT \\
Only eat Halal \& Good Foods & Akhlak Terhadap Rasulullah SAW \\
The Right Hand Please & Akhlak Terhadap Rasulullah SAW \\
Do'a Before You Eat & Akhlak Terhadap Allah SWT \\
Don't Forget Do'a Before You Eat & Akhlak Terhadap Allah SWT \\
Sabar Don't Be Angry & Anjuran Melakukan Akhlak Terpuji \\
Moslem be Honest & Anjuran Melakukan Akhlak Terpuji \\
Moslem be Amanah & Anjuran Melakukan Akhlak Terpuji \\
Start Your Day With Bismillah & Akhlak Terhadap Allah SWT \\
Smile is Shodaqoh & Akhlak Terhadap Sesama Manusia \\
Only Tell The Truth & Anjuran Melakukan Akhlak Terpuji \\
Be Grateful Everyday & Akhlak Terhadap Allah SWT \\
Clean it's Sunnah & Akhlak Terhadap Rasulullah SAW \\
Amazing Shodaqoh & Akhlak Terhadap Sesama Manusia \\
Amazing Shodaqoh, Care \& Share Make Your & Akhlak Terhadap Sesama Manusia \\
Life Worthy & \\
Alhamdulillah Always Syukur & Akhlak Terhadap Allah SWT \\
Sharing is Wonderful & Akhlak Terhadap Sesama Manusia \\
\hline
\end{tabular}

Sumber: Hasil Penelitian

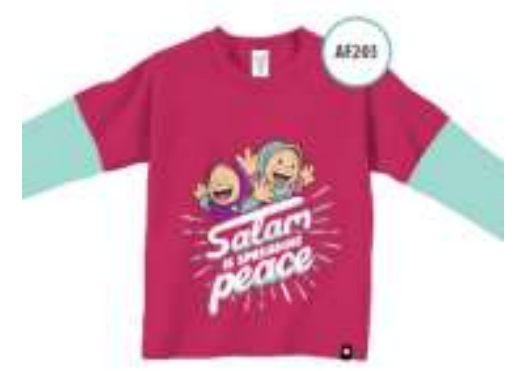

Sumber: Katalog Afrakids

Gambar 2. Salah satu contoh kategorisasi pesan akhlak

Akhlak terhadap Allah SWT dilakukan dengan cara berhubungan dengan Allah SWT melalui media-media yang telah disediakan Allah SWT, yaitu ibadah yang berhubungan langsung kepada Allah SW'T seperti shalat, puasa, haji juga rasa syukur atas segala nikmat yang telah Allah SWT berikan kepada umatnya. Dengan ketentuan syariat ajaran Islam, serta dilakukan dengan ikhlas hanya semata-mata mengharap ridha Allah SWT merupakan bentuk akhlak yang baik terhadap-Nya. Adapun pesan dakwah yang terdapat dalam kaos Afrakids menjelaskan tentang salah satu bentuk akhlak terhadap Allah SWT, yaitu: 
Doa before you eat yang berarti berdoa sebelum makan merupakan salah satu kategori pesan akhlak terhadap Allah SWT. Dalam penjelasan katalognya, Afrakids mengatakan bahwa jika anak ayah dan bunda sering lupa berdoa sebelum makan, kaos ini tentunya tepat untuk mereka. Dapat menjadi pengingat bagi anak atau bahkan orangtua agar tidak lupa berdoa sebelum makan. Diantara Sunnah nabi mengucapkan bismillab sebelum makan, minum dan mengakhirinya dengan memuji Allah SWT. Menyebut nama Allah SWT atau berdoa sebelum makan berfungsi mencegah setan dari ikut berpartisipasi menikmati makanan tersebut. Bacaan bismillah yang sesuai dengan Sunnah adalah cukup dengan bismillah tanpa tambahan ar-Rahman dan ar-Rabim. Dari Amr bin Abi Salamah, Rasulullah SAW bersabda, "Wahai anakku, jike engkau hendak makan ucapkanlah bismillah, makanlah dengan tangan kananmu dan makanlah yang berada di dekatmu." (HR. Thabrani dalam Mu'jam Kabir).

Akhlak terhadap Rasulullah SAW. Mencintai Rasulullah SAW adalah wajib hukumnya, karena termasuk bagian dari iman. Semua orang Islam mengimani bahwa Rasulullah SAW adalah hamba Allah SWT dan utusan-Nya. Dalam mengimani Rasulullah SAW berarti menjalankan ajarannya, menaati perintahnya, mencintai serta memuliakannya, juga menjalankan Sunnahnya. Itulah sebagaimana cara berakhlak terhadap Rasulullah SAW. Adapun pesan dakwah yang terdapat dalam kaos Afrakids menjelaskan tentang salah satu bentuk akhlak terhadap Rasulullah SAW, yaitu:

The Right Hand Please yang artinya gunakan tangan kanan ketika makan merupakan salah satu kategori pesan akhlak dalam anjuran melakukan akhlak terpuji. Anjuran makan menggunakan tangan kanan sangatlah diwajibkan, karena sesungguhnya syaitan makan menggunakan tangan kirinya. Rasulullah SAW biasa menggunakan tangan kanan untuk sebagian besar urusannya yang baik-baik. Termasuk juga dalam masalah makan dan minum beliau senantiasa mendahulukan tangan kanannya.

Akhlak terhadap sesama manusia. Berakhlak terhadap sesama manusia berarti melakukan perbuatan yang baik kepada orang lain. Pada dasarnya manusia adalah makhluk sosial yang hidup bermasyarakat. Sebagai makhluk sosial manusia tidak hanya mengandalkan kekuatannya sendiri, tetapi membutuhkan manusia lainnya dalam beberapa hal tertentu. Untuk itu penting memiliki akhlak yang baik terhadap sesama manusia karena kualitas akhlak seseorang mencerminkan kecerdasan emosi dan rohaninya serta berhubungan dengan cara berfikir dan cara merasa yang dipergunakannya. Adapun pesan dakwah yang terdapat dalam kaos Afrakids menjelaskan tentang salah satu bentuk anjuran melakukan akhlak terhadap sesame manusia, yaitu:

Salam is spreading peace yang artinya salam menyebarkan kedamaian merupakan salah satu kategori pesan akhlak terhadap sesama manusia. Salam berasal dari kata salima yang artinya berkisar pada keselamatan dan terhindar dari segala yang tercela. Dalam salam memiliki makna do'a keselamatan yang menjaga dari segala sesuatu yang membahayakan. Selanjutnya, lebih dari itu salam pun 
dimaknai sebagai kedamaian.

Anjuran melakukan akhlak terpuji. Akhlak terpuji disebut juga dengan akhlakul karimah ataupun akhlakul mahmudah yang artinya segala macam perilaku perbuatan baik yang tampak dalam diri manusia. Akhlak terpuji merupakan sifat-sifat ataupun tingkah laku yang sesuai dengan norma-norma atau ajaran Islam. Berakhlak terpuji berarti menghilangkan semua adat kebiasaan yang tercela kemudian membiasakan adat kebiasaan baik. Adapun pesan dakwah yang terdapat dalam kaos Afrakids menjelaskan tentang salah satu bentuk anjuran melakukan akhlak terpuji, yaitu:

Sabar don't be angry yang artinya sabar janganlah marah juga merupakan salah satu kategori pesan akhlak dalam anjuran melakukan akhlak terpuji. Dalam penjelasan katalognya, Afrakids mengatakan bahwa Islam adalah agama sempurna dan mengajarkan prinsip-prinsip kehidupan dengan sangat baik. Salah satu prinsip yang diajarkan oleh Islam adalah sabar.

Berdasarkan pengertian akhlak menurut (Al-Baqir, 2014: 2) akhlak yang baik dan mulia merupakan sifat Rasulullah SAW dan yang paling utama diantara segala amalan para shaddiqin. Dari berbagai judul kaos tersebut terdapat beberapa pembagian akhlak seperti terhadap Allah, akhlak terhadap rasul, akhlak terhadap sesama manusia dan anjuran melakukan akhlak terpuji. Akhlak dalam Islam bukanlah norma ideal yang tidak dapat diimplementasikan dan bukan pula sekumpulan etika yang terlepas dari kebaikan norma sejati. Namun materi akhlak dalam Islam mengenai sifat dan kriteria perbuatan manusia serta berbagai kewajiban yang harus dipenuhinya.

\section{Kategorisasi Pesan Syariah}

Berdasarkan hasil coding, kategorisasi pesan syariah atau pesan yang berkaitan dengan hukum pada pesan dakwah yang terdapat dalam produk anak muslim Afrakids sebanyak 6 pesan, yaitu:

Tabel 3 Pesan Dakwah Kategori Syariah

\begin{tabular}{ll}
\hline Judul Pesan & Kategorisasi Pesan Syariah \\
\hline Adzan, Let's do Sholat & Anjuran Ibadah \\
I do Sholat 5 Times a Day & Anjuran Ibadah \\
Let's Solat & Anjuran Ibadah \\
Hearing Adzan, Let's do Shalat & Anjuran Ibadah \\
Go Jamaah & Anjuran Ibadah \\
Let's Read Qur'an & Anjuran Ibadah
\end{tabular}

Sumber: Hasil Penelitian 


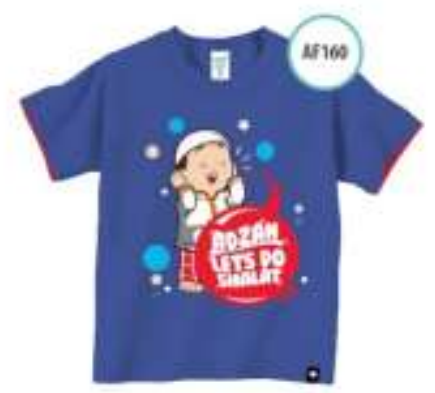

Sumber: Katalog Afrakids

Gambar 3. Salah satu contoh kategorisasi pesan akhlak

Kategorisasi pesan dakwah yang mengacu pada pesan syariah dalam tabel 3 memiliki 6 judul dalam produk anak muslim Afrakids. Syariah merupakan hukum atau syariah sebagai cermin peradaban dalam pengertian bahwa ketika ia tumbuh matang dan sempurna, maka peradaban mencerminkan dirinya dalam hukumhukumnya dalam rangka menaati semua peraturan atau hukum Allah SWT guna mengatur hubungan antara manusia dengan Allah SW'T dan mengatur pergaulan hidup antar sesama manusia. Ketetapan yang mengatur hubungan antara manusia dengan Tuhan disebut Ibadah sedangkan ketetapan yang mengatur pergaulan hidup antar sesama manusia disebut Muamalah.

Ibadah merupakan tata cara menyembah Allah SWT dengan tidak mempersekutukan-Nya yang diwujudkan dalam dua bentuk yaitu: pertama, ibadah mahdlah yang langsung kepada Allah SW'T seperti shalat, ibadah haji, ibadah puasa dan lainnya yang telah ditentukan dalam disiplin ilmu fiqh. Dan kedua, ibadah ghair mahdhoh yang tidak langsung kepada Allah SW'T yakni terkait dengan makhluk Allah SWT seperti santunan kepada kaum dhuafa, gotong royong membangun jembatan, menjaga keamanan dan lainnya. Adapun pesan dakwah yang terdapat dalam kaos Afrakids menjelaskan tentang salah satu bentuk ibadah, yaitu:

Adzan, let's do sholat yang artinya adzan, mari kita lakukan sholat merupakan ajakan untuk menunaikan solat yang termasuk salah satu kategori pesan syariah dalam anjuran ibadah tepatnya ibadah mahdhoh yang langsung kepada Allah SW'T. Dalam penjelasan katalognya, Afrakids mengatakan bahwa kaos adzan, let's do sholat hadir guna memudahkan ayah dan bunda dalam mengajarkan anak-anak untuk segera shalat sesaat setelah adzan berkumandang. Membiasakan shalat di awal waktu kepada anak-anak merupakan hal yang penting, agar saat dewasa nanti mereka tidak menunda-nunda atau bahkan meninggalkan shalat." Adzan merupakan sebuah panggilan bagi umat Islam bahwa telah datang waktu untuk melaksanakan shalat fardhu. Adapun iqamat adalah tanda bahwa shalat akan segera ditunaikan. Rasulullah SAW bersabda yang artinya "JIka adzan untuk shalat 
dikumandangkan, maka pintu-pintu langit dibuka, dan doa-doa dikabulkan” (HR. Ath-Thayalisi). Rasulullah SAW bersabda:

"Sebaik-baiknya amal adalah shalat pada waktunya." Fungsi adzan yaitu panggilan yang dikumandangkan agar umat mengetahui waktu shalat telah datang. Wajib bagi setiap muslim untuk mengerjakan shalat pada waktunya. Sedangkan mengerjakan shalat di awal waktu menunjukan afdholiyah atau keutamaan.

Allah SW'T berfirman dalam al-Qur'an surat an-Nisa ayat 103:

"Selanjutnya, apabila kamu telah menyelesaikan (shalatmu), ingatlah Allah ketika kamu berdiri, padawaktu duduk, dan ketika berbaring. Kemudian apabila kamu telah merasa aman, maka laksanakanlah shalat itu (sebagaimana biasa). Sungguh, shalat itu adalah kewajiban yang ditentukan waktunya atas orang-orang yang beriman.” (Depag RI, 2009: 95)

Shalat awal waktu dicintai Allah SWT, karena saat seorang hamba bergegas melaksanakan shalat di awal waktu, maka itu adalah salah satu ciri yang membuktikan kecintaannya pada Allah SWT.

I do sholat 5 times a day yang artinya saya melakukan shalat lima kali dalam sehari merupakan salah satu kategori pesan syariah dalam anjuran ibadah tepatnya ibadah mahdhoh yang langsung kepada Allah SW'T. Dalam penjelasan katalognya, Afrakids mengatakan bahwa pada sebuah hadist, seorang sahabat nabi yang buta datang ke Rasulullah SAW untuk meminta keringanan shalat 5 waktu di rumah. Rasulullah SAW memberi keringanan tapi beliau menekankan bahwa selama suara adzan terdengar olehnya maka ia wajib menjawab panggilan adzan itu." Perintah melaksanakan shalat lima waktu yang Allah SWT perintahkan kepada umat Islam berawal dari perjalanan Nabi Muhammad ke langit hingga sidratul muntaha ketika mendapat perintah untuk menunaikan shalat lima waktu sehari semalam yang disebut sebagai isra mi'raj. Isra yang berarti perjalanan Rasulullah SAW pada suatu malam dari Masjidil haram di Mekkah ke Masjidil Aqsa di Palestina. Allah SWT berfirman dalam al-Qur'an surat al-Isra ayat 1 berikut:

"Maha Suci (Allah), yang telah memperjalankan hamba-Nya (Muhammad) pada malam hari dari Masjidil Haram ke Masjidil Aqhsa yang telah kami berkahi sekelilingnya agar kami perlihatkan kepadanya sebagian dari tandatanda (kebesaran) kami. Sesungguhnya dia Maha Mendengar, Maha Melihat.” (Depag RI, 2009: 282)

Sedangkan mi'raj secara Bahasa artinya naik. Secara istilah naiknya Rasulullah SAW ke Sidratul Muntaha. Allah SW'T berfirman dalam al-Qur'an surat an-Najm ayat 13-18, berikut:

"Dan sesungguhnya Muhammad telah melihatnya (dalam rupanya yang asli) pada waktu yang lain. (yaitu) di Sidratul Muntaha. Di dekatnya ada surga tempat tinggal. (Muhammad melihat ke Jibril) ketika Sidratul Muntaha diliputi oleh sesuatu yang meliputinya. Penglihatannya (Muhammad) tidak berpaling dari yang dilihatnya itu dan tidak (pula) melampauinya. Sungguh, 
dia telah melihat sebagian tanda-tanda (kebesaran) Tuhannya yang paling besar.” (Depag RI, 2009: 526)

Shalat adalah suatu ibadah yang meliputi ucapan dan peragaan tubuh yang khusus, dimulai dengan takbir dan diakhiri oleh salam. Selain shalat menduduki posisi terpenting dalam Islam yang tidak dapat ditandingi ibadah apapun, juga merupakan fardhu (kewajiban) yang pertama dalam Islam. Allah SWT memfardhukan shalat dengan perintah langsung kepada Rasulullah SAW di sidratul muntaha, sedangkan perintah melaksanakan fardhu lainnya dilakukan di bumi melalui malaikat jibril berikut dengan penjelasan, tata cara, bacaan dan waktunya.

Berdasarkan pengertian ibadah menurut (Sukayat, 2009: 33) merupakan tata cara menyembah Allah SWT dengan tidak mempersekutukan-Nya yang diwujudkan dalam dua bentuk ibadah mahdhah yang langsung terhadap Allah SWT dan ibadah ghair mahdhoh yang tidak langsung kepada Allah SWT. Dalam beberapa judul kaos tersebut terdapat pesan syariah anjuran ibadah yang langsung terhadap Allah SWT atau ibadah mahdhoh. Karena semua judul kaos tersebut membahas tentang sholat, jama'ah dan membaca al-Qur'an yang dilakukan langsung kepada Allah SW'T.

\section{PENUTUP}

Berdasarkan hasil penelitian yang dilakukan dalam 34 judul konten kaos dari 7 tema kaos yang diambil langsung dari katalog resmi Afrakids, peneliti hanya menganalisa pesan dakwah yang terkandung dalam produk tersebut ke dalam hasil pengkodingan yang hanya 26 judul kaos.

Penelitian ini bertujuan untuk mengetahui isi pesan dakwah yang ada dalam konten kaos produk anak muslim Afrakids. Secara lebih rinci tujuan dari penelitian ini adalah untuk mengetahui kategorisasi pesan dakwah meliputi pesan akidah, pesan akhlak serta pesan syariah yang ada pada katalog kaos tersebut.

Berdasarkan hasil analisa serta peng-coding-an yang peneliti lakukan terhadap produk anak muslim Afrakids mengenai pesan dakwah yang terkandung dalam setiap konten katalog produk anak muslim kaos Afrakids, dapat diperoleh hasil sebagai berikut: pertama, pesan dakwah kategorisasi akidah dari tujuh tema katalog kaos Afrakids yang memiliki 26 judul kaos yang diteliti sesuai coding memiliki kategori pesan akidah dengan jumlah 2 pesan dakwah atau persentase sebanyak $7,7 \%$ dengan judul kaos under the sea it's my rabb's creation dan earth \& sky are my rabb creation. Keduanya merupakan kategori pesan akidah beriman kepada Allah SWT. Hasil pesan dakwah kategori pesan akidah memiliki pesan dakwah yang paling sedikit diantara yang lainnya. Kedua, pesan dakwah kategorisasi akhlak dari tujuh tema katalog kaos Afrakids yang memiliki 26 judul kaos yang diteliti sesuai coding memiliki kategori pesan akhlak dengan jumlah 18 pesan dakwah atau persentase sebanyak 69,2\% dengan judul kaos salam is spreading peace, albamdulillah I finished my meal, only eat halal and good foods, the right hand please, do'a before you eat, don't forget do'a 
before you eat, sabar don't be angry, moslem be honest, moslem be amanah, start your day with bismillah, smile is shodaqoh, only tell the truth, be grateful everyday, clean it's Sunnah, amazing shodaqoh, amazing shodaqoh care and share make your life worthy. Pesan dakwah kategorisasi akhlak merupakan pesan yang paling banyak dalam kaos Afrakids, karena sesuai dengan hadirnya Afrakids untuk membuat perubahan besar di tengah masyarakat, pesan akhlak yang menjadi dasar perilaku manusia paling banyak ditanamkan dalam diri anak. Ketiga, pesan dakwah kategorisasi syariah dari tujuh tema katalog kaos Afrakids yang memiliki 26 judul kaos yang diteliti sesuai coding memiliki kategori pesan syariah sebanyak 6 pesan dakwah atau persentase sebanyak 23,1\% dengan judul kaos adzan lets do shalat, I do shalat 5 times a day, lets shalat, hearing adzan lets do shalat, go jamaah, let's read qur'an. Pesan dakwah kategorisasi syariah merupakan pesan yang memiliki tingkat paling banyak kedua setelah pesan akhlak.

\section{DAFTAR PUSTAKA}

Darmawan, A. dkk.,. (2002). Metodologi Ilmu Dakwah. Yogyakarta: Lembaga Studi Filsafat Islam.

Ardi, M D. (2013). Psikologi Dakwah. Bandung: CV Mimbar Pustaka.

Diakses 9 Januari 2018, dari https:/ /www.afrakids.com/produk/

Fiske, J. (2011). Memahami Budaya Populer. Yogyakarta: Jalasutra.

Ilaihi, W. (2013). Komunikasi Dakwah. Bandung: PT Remaja Rosdakarya.

Imanto, T. (2012). Budaya Populer dan Realitas Media dalam scribd: www.esaunggul.ac.id 1-13.

Liliweri, A. (2011). Komunikasi: Serba Ada Serba Makna. Jakarta: Kencana Prenada Media Group.

Munir, M. (2003). Metode Dakwah. Jakarta: Prenadamedia.

Munir, M., Ilaihi, W. (2009). Manajemen Dakwah. Jakarta: Kencana Prenada Media Group.

Mubasyaroh. (2017). "Strategi Dakwah Persuasif dalam Mengubah Perilaku Masyarakat." Ilmu Dakwah: Academic Journal for Homiletic Studies [Online], 11.2 311-324. Web. 30 Sep. 2018

Muhibin, W L. (2015). Psikologi Komunikasi. Bandung: Pustaka Setia.

Nata, A. (2009). Metodologi Studi Islam. Jakarta: PT Raja Grafindo Persada.

Rahmanto, A. (2009). Media \& Budaya Populer. November 19. Accessed Juli 7, 2018, dari https://www.slideshare.net/andreyuda/media-dan-budayapopuler

Simatupang, L L. (2006). Tato, Yogyakarta: LKIS Yogyakarta.

Strinati, D. (2007). Popular Culture. Yogyakarta: Jejak.

Sukayat, T. (2009). Quantum Dakwah. Jakarta: PT Asdi Mahastya.

Sumijati, S. (2004). Komunikasi Penyiaran Islam. Bandung: Benang Merah Press.

Wahyudi, D. (2017). Pengantar Akidah Akhlak dan Pembelajarannya. Yogyakarta: Lintang Rasi Aksara Books.

Wikipedia (2017). Budaya, diakses 23 November 2018, dari 
S. Nurjamilatunnisa, A. Sarbini, \& M. Fakhruroji

https://id.wikipedia.org/wiki/Budaya 